\title{
Gender-Related Effect of Sodium Dichloroacetate on the Number of Hassall's Corpuscles and RNA NKCC1 Expression in Rat Thymus
}

\author{
Jūratė Stanevičiūtè, ${ }^{1}$ Milda Juknevičienè, ${ }^{1}$ Ingrida Balnytė, ${ }^{1}$ Angelija Valančiūtè $\mathbb{C D}^{1}{ }^{1}$ \\ Vaiva Lesauskaitė $\mathbb{D},{ }^{2}$ Julija Fadejeva, ${ }^{3}$ Rimantas Stakauskas, ${ }^{4}$ and Donatas Stakišaitis $\mathbb{D}{ }^{1,3}$ \\ ${ }^{1}$ Department of Histology and Embryology, Medical Academy, Lithuanian University of Health Sciences, Kaunas, LT 44307, Lithuania \\ ${ }^{2}$ Institute of Cardiology of Lithuanian University of Health Sciences, Kaunas, LT 50009, Lithuania \\ ${ }^{3}$ Laboratory of Molecular Oncology, National Cancer Institute, LT 08660 Vilnius, Lithuania \\ ${ }^{4}$ Biological Research Center, Lithuanian University of Health Sciences, Kaunas, LT 47181, Lithuania \\ Correspondence should be addressed to Donatas Stakišaitis; donatas.stakisaitis@lsmuni.lt
}

Received 24 July 2018; Revised 26 February 2019; Accepted 8 April 2019; Published 24 April 2019

Academic Editor: Vasiliki Galani

Copyright (C) 2019 Jūratè Stanevičiūte et al. This is an open access article distributed under the Creative Commons Attribution License, which permits unrestricted use, distribution, and reproduction in any medium, provided the original work is properly cited.

\begin{abstract}
The aim was to investigate the effect of dichloroacetate (DCA) on thymus weight, Hassall's corpuscle number (HCs), and NKCC1 RNA expression in Wistar rats aged 4-5 weeks. They were investigated in the controls and DCA-treated gonad-intact and castrated males and females. The treatment lasted 4 weeks with DCA $200 \mathrm{mg} / \mathrm{kg} / \mathrm{day}$. At the end of the experiment, rat thymus was weighted, and its lobe was taken for the expression of NKCC1 RNA determined by the PCR method and of Hassall's corpuscles by immunohistochemistry. DCA caused a thymus weight decrease in DCA-treated gonad-intact rats of both genders as compared with their controls $(\mathrm{p}<0.05)$, and no such impact was found in castrated DCA-treated males and females. DCA caused an increase of the HCs in gonad-intact males $(\mathrm{p}<0.05)$, and no such increase in the DCA-treated gonad-intact females was found. There was gender-related difference in the HCs when comparing DCA-treated gonad-intact males and females: males showed significantly higher HCs $(\mathrm{p}<0.05)$; no gender-related differences were found in the castrated DCA-treated groups. The Slc12a2 gene RNA expression level was found to be significantly decreased only in gonad-intact and in castrated DCA-treated males. The authors discuss the gender-related DCA effects on the thymus.
\end{abstract}

\section{Introduction}

Sodium dichloroacetate (DCA) is an inhibitor of pyruvate dehydrogenase kinase (PDHK) [1]. DCA is absorbed from the gastrointestinal tract and transported across the cell membrane by the monocarboxylate transporter system and metabolized to monochloroacetate, glyoxylate, glycolate, oxalate, glycine, carbon dioxide, and chloride anion [2-4].

The DCA principal target is the pyruvate dehydrogenase complex (PDC). It inhibits all isoforms of PDHK, keeping PDC in the catalytically active form facilitating the oxidative removal of pyruvate. PDHK isoforms can phosphorylate Ela (PDHA1), thus inactivating it; the mechanism for PDC inhibition is related with the posttranscriptional upregulation of one or more PDHK isoforms, leading to phosphorylation of the Ela subunit of PDC and maintaining the glycolytic profile of proliferating cells $[1,5,6]$.

The PDHA1 gene is located on the $\mathrm{X}$ chromosome, and such gene location has different consequences for males and females with PDHAl congenital deficiency; gender-related clinical problems depend mainly on the residual PDHA1 enzyme activity; PDC congenital or acquired deficiency may be a cause of lactic acidosis [7-9].

Pyruvate dehydrogenase is present in normal and in cancer tissues, and the PDC/PDHK axis has been suggested as a specific target in cancer treatment $[10,11]$. DCA has been employed for indication in the chronic treatment seeking to decrease the blood lactate acid level in congenital lactic 
acidosis [12] or to inhibit the anaerobic glycolysis which renders various cancer cells resistant to apoptosis induction [13]. DCA induces apoptosis, cell cycle arrest, reverses the Warburg effect in cancer cells $[11,14,15]$, increases apoptosis via the intrinsic mitochondrial pathway due to the high reactive oxygen species causing mitochondrial depolarization, decreases the ATP production, and effectively kills tumor cells $[16,17]$.

Thymus could be a valuable model for investigating the effect of medicinal products on thymocyte proliferation. Following castration, hyperplasia of thymus and gender-related increase in the Hassall's corpuscles number (HCs) in thymus appear in rats [18]. HCs are related to the loss of apoptotic thymocytes and maturation of developing thymocytes [19]. The DCA treatment shows efficacy in reducing proliferation in highly proliferating normal cells, e.g., rat thymocytes; it has been related with thymus weight loss in gonad-intact DCAtreated male rats and a decrease of the thymocyte number in the $G_{0}-G_{1}$ phase as well as thymocyte accumulation in the $\mathrm{G}_{2}-\mathrm{M}$ phase, but no significant effect was found on thymus weight or thymocyte cell cycle in DCA-treated castrated males, indicating that DCA works synergistically with gonad hormones in males [20].

Recently, we reported inhibition of $\mathrm{Na}^{+} / \mathrm{K}^{+} / 2 \mathrm{Cl}^{-}$cotransporter (NKCC) by DCA in male rats: (1) a single dose significantly increased 24-hour urinary output as well as $\mathrm{Cl}^{-}$, $\mathrm{Na}^{+}, \mathrm{K}^{+}, \mathrm{Ca}^{2+}$, and $\mathrm{Mg}^{2+}$ excretion; (2) changes following 4 -week treatment included increase in the size of the Henle loop's thick ascending limb's epithelial cells (an effect related to NKCC2 inhibition) and (3) significant decrease in RNA NKCC1 expression in thymus of male rats [21]. The intracellular chloride level in rat thymocytes partially is regulated by chloride influx via the NKCC1 functional activity [22, 23]. The NKCC1 gene also is known as a solute carrier family 12, member 2 (Slc12a2). This gene was found to be broadly expressed in thymus $[24,25]$. NKCC1 participates in cell proliferation and tumorigenesis processes [26].

J. A. Clayton (2014) noted that female and male cells differ in their response to chemical agents but preclinical research often neglects association of medicines effects with gender and sex hormones [27]. We did not find any study on genderrelated effects of DCA on thymus in literature. The article presents data on gender-related effect of repeated dosing of DCA on thymus of normal and castrated rats of both genders including its weight, Hassall's corpuscle number, and NKCC1 RNA expression.

\section{Materials and Methods}

2.1. Study Design. The effect of the DCA treatment on the thymus was investigated in the following 8 groups of age-matched Wistar rats of both genders: gonad-intact and castrated male and female controls and in respective male and female DCA-treated groups.

The permission was obtained from the State Food and Veterinary Service of Lithuania to use experimental animals for research (2015-05-18 No. G2-28). The animals were purchased from the Animals Facility of the Veterinary Academy at the Lithuanian University of Health Sciences (Kaunas,
Lithuania). The experiment was carried out at the Animal Research Center at the Lithuanian University of Health Sciences (Kaunas, Lithuania). The animals were housed in standard colony cages with free access to food, in the conditions of constant temperature $\left(21 \pm 1^{\circ} \mathrm{C}\right)$, humidity, and the light /dark cycle ( $12 \mathrm{~h} / 12 \mathrm{~h})$. A commercial pellet diet was provided ad libitum. The experiments were performed in compliance with the relevant laws and institutional guidelines for animal care in order to avoid any unnecessary animal distress.

For the experiment, 4-5-week aged Wistar rats were selected with the same animal number $(n=6)$ in the groups; there was no difference in rat weight among the formed groups. In the animal groups selected for castration, the male orchidectomy and female ovariectomy operations were performed. The castration was performed at the age of $28 \pm 2$ days (in the peripubertal period of animals). The accommodation period after the castration was one week. After the accommodation period, the treatment of gonad-intact and castrated animals was started. At the end of the experiment, one castrated DCA-treated female was eliminated from the study due to a fistula formed after the operation and significant weight loss.

Treatment with DCA aqueous solutions (200 mg/kg/day) in drinking water was used. The only source of drinking was the DCA solution for treated groups, and fresh tap water was provided for the control groups; DCA solution and water were offered to animals ad libitum. The treatment duration was 4 weeks. The DCA dosage, administration in drinking water, and thymus preparation methods were described as previously [20].

2.2. The Thymus Preparation. Completing the experiment, the animals were killed in a $70 \% \mathrm{CO}_{2}$ camera. To minimize the thymus contamination with red blood cells, the carotid arteries and the aorta were cut and the animals exsanguinated. Upon killing the animals, their thymus was harvested and the contaminating blood was removed by rinsing with RPMI-1640 (Biological Industries, Israel). The weight of the thymus was evaluated, and the left rat thymus lobe samples of the study groups after thymus surrounding connective tissue were removed and the thymus lobe was stored in the RNAlaterRNA stabilization reagent (Qiagen, Germany) at $-80^{\circ} \mathrm{C}$ until the further RNA extraction and RNA analysis. The right lobe of the thymus was taken for the histomorphometric evaluation.

2.3. The HCs Determination by Histology. The right lobe of the thymus was fixed in $10 \%$ neutral-buffered formalin, embedded in paraffin, sectioned in $3 \mu \mathrm{m}$ sections, and stained with hematoxylin and eosin (H-E). For immunohistochemical examination, slices were placed on poly-L-lysinecoated glass slides. After deparafinization in xylene and rehydration, the sections were pretreated with the antigen-retrieval solution $(0.01 \mathrm{~mol} / \mathrm{L}$ of citrate buffer, $\mathrm{pH} 6)$ in a pressurecooker and then incubated with cytokeratin monoclonal antibodies (clone 34 E12, dilution 1:50, Dako A/S, Denmark) for the identification of high molecular weight cytokeratins (HMW CK). Antibodies detection was performed with 
the EnVisionPlus-HRP kit (Dako, Denmark). Sections were counter-stained in weak Mayer's hematoxylin. The histological and immunohistochemical evaluation of the samples was performed with an OLYMPUS BX40F4 (Olympus Opticae co. LTD, Japan) microscope using the CellSens Dimention 1.9 Digital Imaging Software for Research Applications (Olympus Corporation of the Americas, USA). Histological sections were selected from the middle portion of the right thymus lobe. The total area of the thymus lobe and the area of the medulla were counted. The presence of Hassall's corpuscules, which are heterocellular, consisting of thymic epithelial cells (major cellular component), macrophages, interdigitating dendritic cells, myoid cells, and, occasionally, mast cells and lymphocytes [28] was evaluated and were counted in the medulla. The data are presented as the median per $\mathrm{mm}^{2}$ of thymus medulla in each group. The methodology of the HCs histological examination was as described previously [18].

\subsection{Extraction of RNA from the Thymus. Rat thymus samples} of all study groups were stored in RNAlaterRNA stabilization reagent (Qiagen, Germany) at $-80^{\circ} \mathrm{C}$ until further RNA extraction. The frozen tissue was ground in liquid nitrogen. Total RNA was extracted using the TRIzol ${ }^{\mathrm{TM}}$ Plus RNA Purification Kit (Life Technologies, USA) according to the manufacturer's instruction. The RNA quality was assessed using a NanoDrop2000 spectrophotometer (Thermo Scientific, USA) using the A260/280 ratio. The extracted RNA samples were stored at $-80^{\circ} \mathrm{C}$ until further analysis. The methodology of RNA extraction and the evaluation of the NKCC1 expression in thymus were used analogically as described [21].

\subsection{Determination of the NKCC1 Expression in Thymus.} RNA expression assay was performed for Slc12a2 (Rn00582505_ml) and Glpdh (Rn01775763_g1) genes. High-Capacity cDNA Reverse Transcription Kit with RNase Inhibitor (Applied Biosystems, USA) was used for reverse transcription reaction in $20 \mu \mathrm{l}$ reaction volume containing $50 \mathrm{ng}$ of total RNA incubated at $25^{\circ} \mathrm{C}$ for $10 \mathrm{~min}$, transcripted at $37^{\circ} \mathrm{C}$ for $120 \mathrm{~min}$, and terminated by heating at $85^{\circ} \mathrm{C}$ for 5 min using Biometra TAdvanced thermocycler (Analytik Jena AG, Germany). The synthesized cDNA was stored at $4^{\circ} \mathrm{C}$ until use or at $-20^{\circ} \mathrm{C}$ for longer time. The Real-time PCR was run in triplicate with $4 \mu \mathrm{l}$ of cDNA template in a $20 \mu \mathrm{l}$ reaction volume (10 $\mu \mathrm{l}$ of TaqMan Universal Master Mix II, no UNG (Applied Biosystems, USA), $1 \mu$ l of TaqMan Gene Expression Assay 20x (Applied Biosystems, USA), and $5 \mu \mathrm{l}$ of Nuclease-Free Water (Invitrogen, USA) with the program running at $95^{\circ} \mathrm{C}$ for $10 \mathrm{~min}$, followed by 40 cycles of $95^{\circ} \mathrm{C}$ for $15 \mathrm{~s}$ and $60^{\circ} \mathrm{C}$ for $1 \mathrm{~min}$. the reaction was performed using an Applied Biosystems 7900 Fast Real-Time PCR System (Applied Biosystems, USA).

2.6. Statistical Analysis. The statistical analysis was performed by using the Statistical Package for the Social Sciences, version 22.0 for Windows (IBM SPSS Statistics V22.0, USA). The normality assumption was verified by the Kolmogorov-Smirnov test. The animal weight data are expressed as the mean \pm SD values. The thymus weight data are presented as the mean and the 95\% confidence interval (95\% CI). When the normality assumptions are not met, data are expressed as a median and a range (minimum and maximum values). Differences between two independent groups were evaluated using the nonparametric the Mann-Whitney $U$ test. The one-way ANOVA analysis was used to determine significance among the groups, and post hoc tests with Fisher's least significant difference were used for comparison among the individual groups. To investigate the NKCC1 (Slc12a2) RNA expression changes in the DCA-treated group, the threshold cycle (CT) values were normalized with the control Glpdh gene; for the gene expression study, the delta delta threshold cycle $\left(2^{-\Delta \Delta C T}\right)$ method was used to calculate the expression ratio between the DCA-treated (test) and control conditions of the target gene as compared with the reference gene. The Spearman's rank correlation coefficient $(r)$ was used to assess the relationship among thymus weight, HCs and $\triangle \mathrm{CT}$. The Fisher's transformation which changes $r$ to a Z-score and the Steiger's Z-test for comparison of correlations $(z)$ within the population were used. Differences at the value of $p<0.05$ were considered significant.

\section{Results}

3.1. The Relationship of the Rat Thymus Weight with the Rat Weight in the Study Groups. The data of rat thymus weight of the study groups after the treatment and their control groups are summarized in Table 1 . No difference of the initial rat body weight was found between the control female and male groups (respectively, $77.33 \pm 15.28$ and $70.33 \pm 6.81, \mathrm{p}>$ 0.05 ) and the other study groups formed for castration and treatment did not differ according to body weight $(\mathrm{p}>0.05)$.

At the end of the experiment, the gonad-intact males had a significantly higher body weight as compared with the gonad-intact female control $(255.89 \pm 48.30$ and 191.62 $\pm 23.64, \mathrm{p}<0.007)$, and there was no significant rat body weight difference when comparing the gonad-intact male control and the gonad-intact DCA-treated males ( $p>0.05$ ); no difference was found between the respective female groups $(\mathrm{p}>0.05)$.

The castrated DCA-treated rat groups of both genders showed a statistically significant body weight decrease as compared with the castrated control groups: the body weight of castrated DCA-treated males was by $15.07 \%$ lower than that of the control $(245.12 \pm 17.53 \mathrm{~g}$ and $208.17 \pm 22.78 \mathrm{~g} ; \mathrm{p}<0.011)$ and by $16.76 \%$ lower in the DCA-treated females as compared with their control $(229.80 \pm 20.84 \mathrm{~g}$ and $191.28 \pm 24.50 \mathrm{~g} ; \mathrm{p}<$ $0.02)$.

3.2. The Data on the Effect of Castration and Treatment on the Rat Thymus Weight. The data on the effect of DCA treatment on thymus weight are shown in Table 1 and Figure 1.

A comparison of the gonad-intact control and the castrated control of both gender groups indicated a statistically significant thymus weight increase in castrated males ( $p$ $=0.02)$ and females $(p=0.001)$ control groups, because castration is related with thymus hyperplasia. There was no gender-related difference in animal thymus weight when 
TABLE 1: The rat thymus weight data in male and female study groups.

\begin{tabular}{|c|c|c|}
\hline \multirow[t]{2}{*}{ Study group } & \multicolumn{2}{|c|}{$\begin{array}{c}\text { Thymus weight }(\mathrm{g}) \\
\text { mean }(95 \% \mathrm{CI})\end{array}$} \\
\hline & males & females \\
\hline $\begin{array}{l}\text { Gonad-intact rats: } \\
\text { control }\end{array}$ & $0.61(0.47-0.78)$ & $0.48(0.42-0.56)$ \\
\hline DCA-treated & $0.38(0.33-0.43)^{\mathrm{a}}$ & $0.32(0.27-0.37)^{\mathrm{b}}$ \\
\hline $\begin{array}{l}\text { Castrated rats: } \\
\text { control }\end{array}$ & $0.80(0.69-0.92)^{\mathrm{a}}$ & $0.85(0.64-1.06)^{\mathrm{b}}$ \\
\hline DCA-treated & $0.69(0.58-0.80)$ & $0.65(0.46-0.84)$ \\
\hline
\end{tabular}

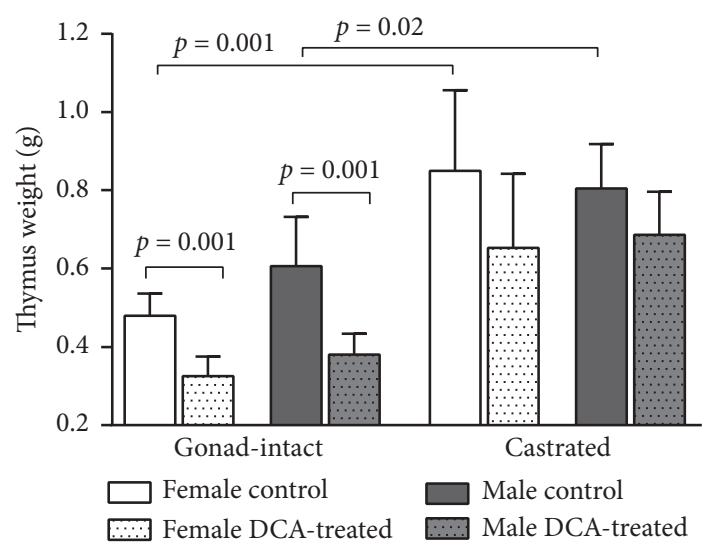

Figure 1: DCA treatment impact on rat thymus weight in gonadintact and castrated rat groups of both genders. Data presented as a mean and $95 \%$ confidence interval.

comparing gonad-intact male and female as well as castrated rats $(p>0.05$; Table 1$)$.

The DCA treatment causes a significant thymus weight decrease in DCA-treated gonad-intact males $(p=0.001)$ and DCA-treated gonad-intact females $(p=0.001)$ as compared with their controls. No significant treatment impact was found in castrated DCA-treated male and female groups when comparing with their castrated controls $(p>0.05$; Figure 1).

3.3. The Data on the Effect of Castration and Treatment on the Number of Hassall's Corpuscles in Rat Thymus. The HCs in the thymus of the studied groups are presented in Table 2.

The HCs appeared to be low in male and female thymus of gonad-intact control rat groups. There was a significant difference in the HCs between control gonad-intact and control castrated groups in males $(p=0.002)$ and females $(p=$ 0.009 ). The treatment of rats with DCA caused a statistically significant increase of HCs in the male as compared with the gonad-intact control group ( $p=0.002$; Figure 2$)$. The DCA treatment tends to increase the HCs in the female gonad-intact group, but no significant difference was found $(p>0.05)$. A significant difference in the HCs was found between DCA-treated gonad-intact males and females ( $p$
TABLE 2: The number of Hassall's corpuscles in thymus of the study groups.

\begin{tabular}{|c|c|c|}
\hline \multirow[t]{2}{*}{ Study group } & \multicolumn{2}{|c|}{$\begin{array}{c}\text { Number of HCs per } \mathrm{mm}^{2} \\
{[\text { median (range) }]}\end{array}$} \\
\hline & males & females \\
\hline $\begin{array}{l}\text { Gonad-intact rats: } \\
\text { control }\end{array}$ & $0.05(0-0.16)$ & $0.05(0-0.26)$ \\
\hline DCA-treated & $0.48(0.18-1.0)^{\mathrm{a}}$ & $0.2(0.07-0.48)$ \\
\hline $\begin{array}{l}\text { Castrated rats: } \\
\text { control }\end{array}$ & $0.26(0.22-0.55)^{\mathrm{b}}$ & $0.28(0.16-0.49)^{\mathrm{c}}$ \\
\hline DCA-treated & $0.4(0.15-0.62)$ & $0.26(0.07-0.34)$ \\
\hline
\end{tabular}

$=0.04$ ), and males showed a significantly higher Hassall's corpuscle number. However, none of such differences were statistically significant in the castrated DCA-treated groups of both genders when comparing with the castrated control groups ( $p>0.05$; Figure 3 ).

Comparison of the correlation between thymus weight and HCs of gonad-intact males and females controls with, respectively, correlations of DCA-treated groups shows that DCA treatment changes the relationship character: the correlations have positive direction in controls but after the repeated DCA dosage the correlation became negative; a comparison of correlation coefficients of gonad-intact DCAtreated males with their control revealed significant difference $(p=0.004)$. The correlation between thymus weight and HCs in gonad-intact and castrated DCA-treated male groups was significant ( $p=0.005$ and $p<0.04$, respectively, Figure 4 ). No significant data regarding the correlation between thymus weight and HCs in tested female groups were detected (Table 3).

3.4. The DCA Effect on RNA Expression of NKCC1 in Thymus. Slc12a2 RNA expression in the thymus after normalization with Glpdh gene in analyzed rats groups is shown in Table 4.

Expression difference in the Slc12a2 and Glpdh genes between the DCA-treated and the control groups is considered as the $\Delta \mathrm{CT}$ value. The Slc12a2 RNA levels in experimental groups after normalization with the Glpdh gene are shown in Figure 5. A significant difference was found between the $\triangle \mathrm{CT}$ values of the gonad-intact male control and DCAtreated groups $(\mathrm{p}<0.0001)$. In the castrated male group, the expression of the Slc12a2 and Glpdh genes between the DCA-treated and the control groups was also significant $(p=0.015)$. The difference between the $\Delta C T$ of target and reference genes as expressed by the $\Delta \Delta \mathrm{CT}$ is shown in Table 4 . The RNA expression level $\left(2^{-\Delta \Delta C T}\right)$ in the gonad-intact DCAtreated male was 0.103 -fold change lower than in the control. This means the $90 \%$ downregulation of expression as the expression level is decreased by $90 \%$ to the level of $10 \%$ under control conditions. Also, there was a significant Slc12a2 gene expression change in the castrated male DCA-treated group as compared with the control: its expression level was found to be decreased by $76 \%$ (Table 4 ). However, we found 


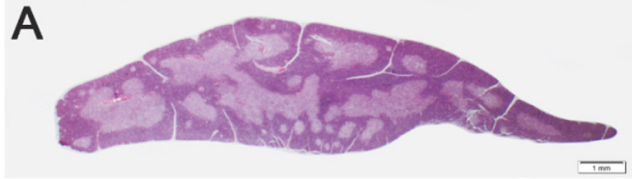

(a)

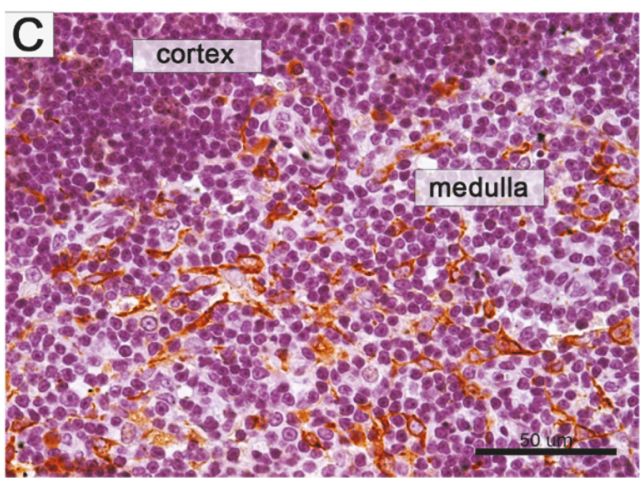

(c)

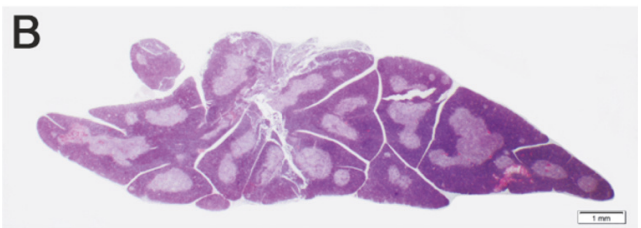

(b)

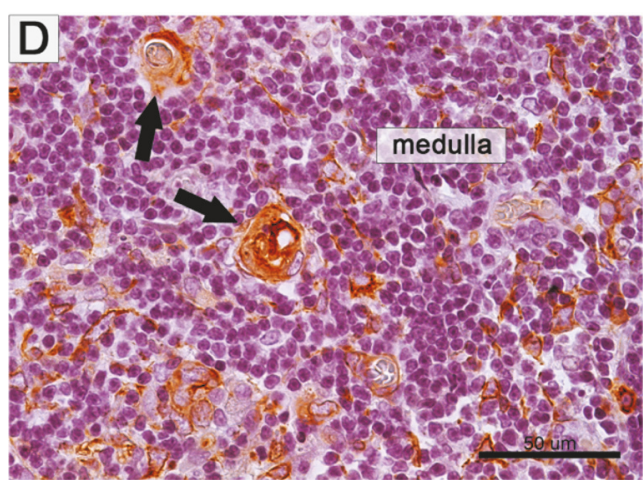

(d)

FIGURE 2: Morphological changes of rat thymus: a comparison of the male gonad-intact control and the male castrated control groups. (a) the male gonad-intact control group; (b) the male castrated control group (size of the male thymus increased after castration); (c) Hassall's corpuscles are not present in the male gonad-intact control rat thymus; thymic epithelial cells are positive for high molecular weight cytokeratins (clone 34 $\beta \mathrm{E} 12$ ). Streptavidin-biotin-peroxidase, hematoxylin counterstain; (d) Hassall's corpuscles (arrows) are present in the medullar region of thymus in the male castrated control group and positive for high molecular weight cytokeratins. Scale bar: $1 \mathrm{~mm}(\mathrm{a}$ and b), $50 \mu \mathrm{m}$ (c and d).

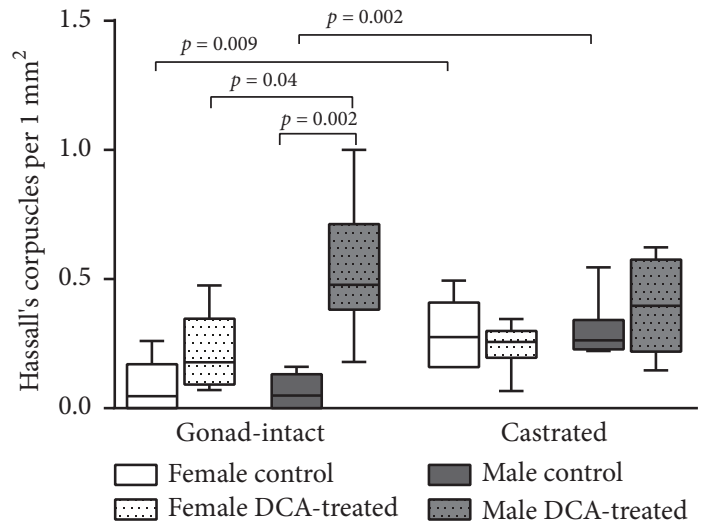

Figure 3: The Hassall's corpuscles number per $\mathrm{mm}^{2}$ in thymus of the gonad-intact and castrated rat groups of both genders. Data presented as a median and range (min-max).

no statistical significance in the test RNA expression when comparing the control and the DCA-treated groups in both gonad-intact and castrated female rats $(\mathrm{p}>0.05)$.

The correlation of thymus weight with $\Delta \mathrm{CT}$ in the controls and in the DCA-treated gonad-intact and castrated groups of both genders was insignificant ( $p>0.05$ ); no significant differences comparing correlation coefficients of the control with the DCA-treated, respectively, groups were found ( $p>0.05$; Table 3$)$.
TABLE 3: Correlation ( $r$ among thymus weights, Hassall's corpuscles number per $\mathrm{mm}^{2}, \Delta \mathrm{CT}$, and $\mathrm{Z}$ test value $(z)$ of the study groups.

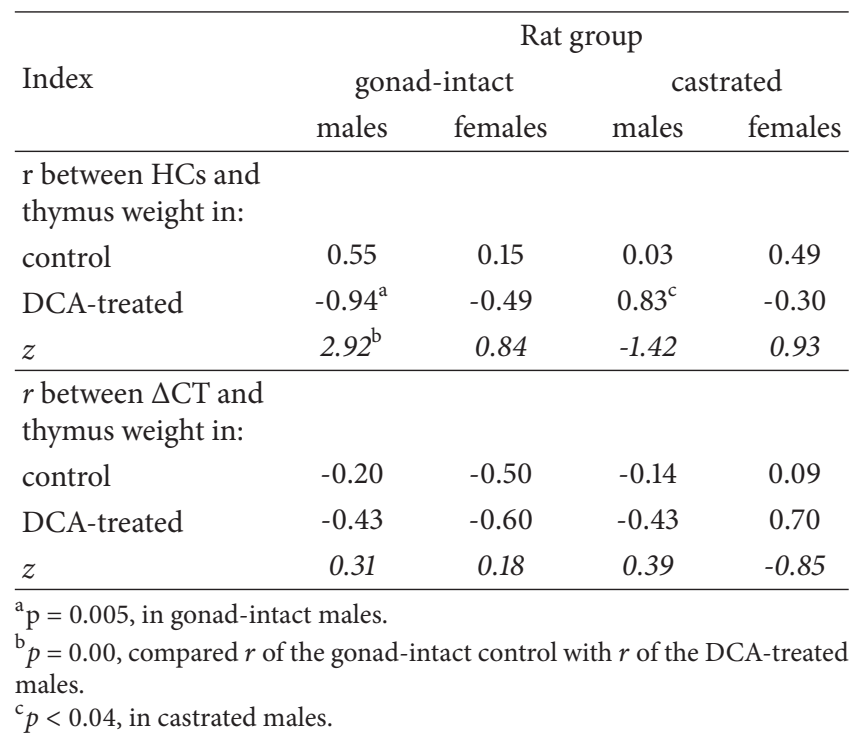

\section{Discussion}

DCA has been employed as an investigational medicine for indication in the chronic treatment of conditions related to pathologically increased cell proliferation such as cancer and pulmonary hypertension $[1,10,14]$. The DCA principal site 
TABLE 4: RNA expression of NKCC1 in thymus of the study groups.

\begin{tabular}{|c|c|c|c|c|c|}
\hline \multirow{2}{*}{ Study group } & \multicolumn{2}{|c|}{ CT average } & \multirow{2}{*}{$\Delta \mathrm{CT}$} & \multirow{2}{*}{$\Delta \Delta \mathrm{CT}$} & \multirow{2}{*}{$2^{-\Delta \Delta C T}$} \\
\hline & Glpdh & Slc12a2 & & & \\
\hline \multicolumn{6}{|c|}{ Gonad-intact female: } \\
\hline control & 23.529 & 31.130 & 7.600 & \multirow{2}{*}{-2.558} & \multirow{2}{*}{5.890} \\
\hline DCA-treated & 24.183 & 29.225 & 5.042 & & \\
\hline \multicolumn{6}{|c|}{ Gonad-intact male: } \\
\hline control & 26.298 & 27.406 & 1.108 & \multirow{2}{*}{3.283} & \multirow{2}{*}{0.103} \\
\hline DCA-treated & 23.710 & 28.101 & $4.391^{\mathrm{a}}$ & & \\
\hline \multicolumn{6}{|c|}{ Castrated female: } \\
\hline control & 22.675 & 30.115 & 7.440 & \multirow{2}{*}{-0.362} & \multirow{2}{*}{1.285} \\
\hline DCA-treated & 21.791 & 28.869 & 7.079 & & \\
\hline \multicolumn{6}{|c|}{ Castrated male: } \\
\hline control & 24.717 & 30.646 & 5.929 & \multirow{2}{*}{2.048} & \multirow{2}{*}{0.242} \\
\hline DCA-treated & 20.912 & 28.889 & $7.977^{\mathrm{b}}$ & & \\
\hline
\end{tabular}

${ }^{a} p<0.0001$, DCA-treated gonad-intact males compared with their control.

$\mathrm{b}_{p}=0.015$, DCA-treated castrated male compared with their control.

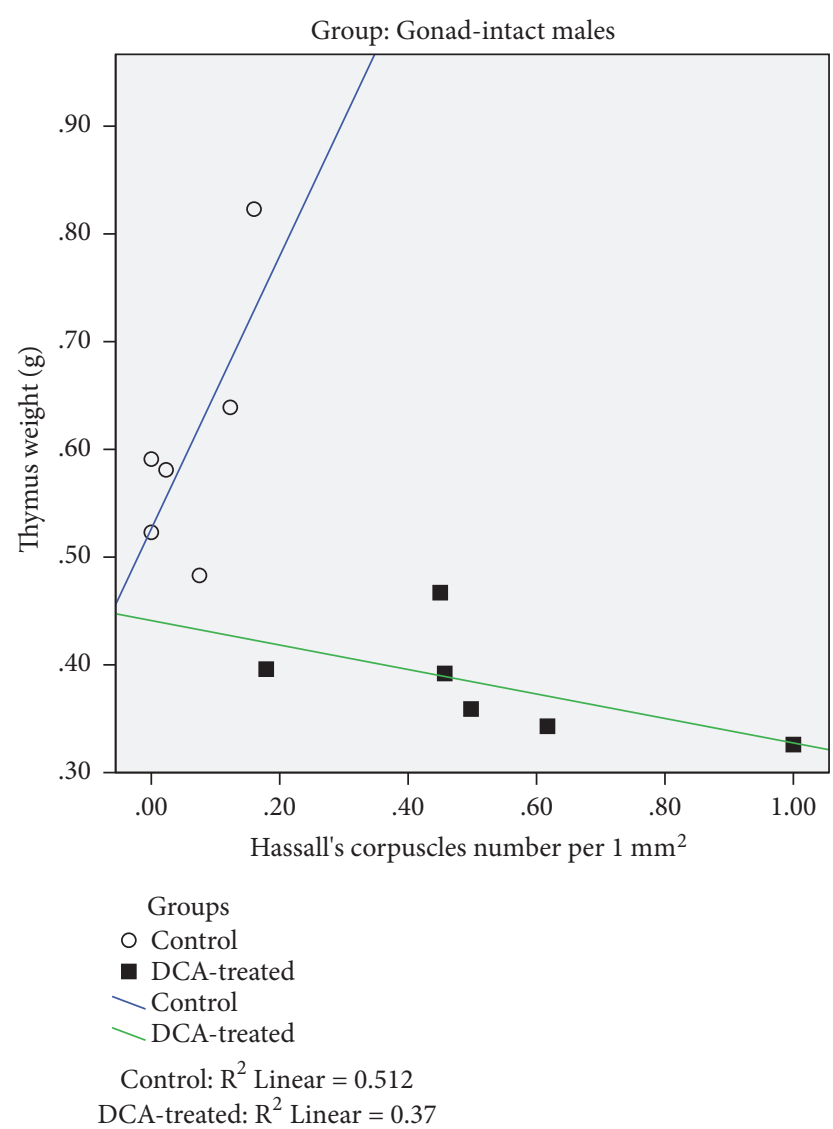

(a)

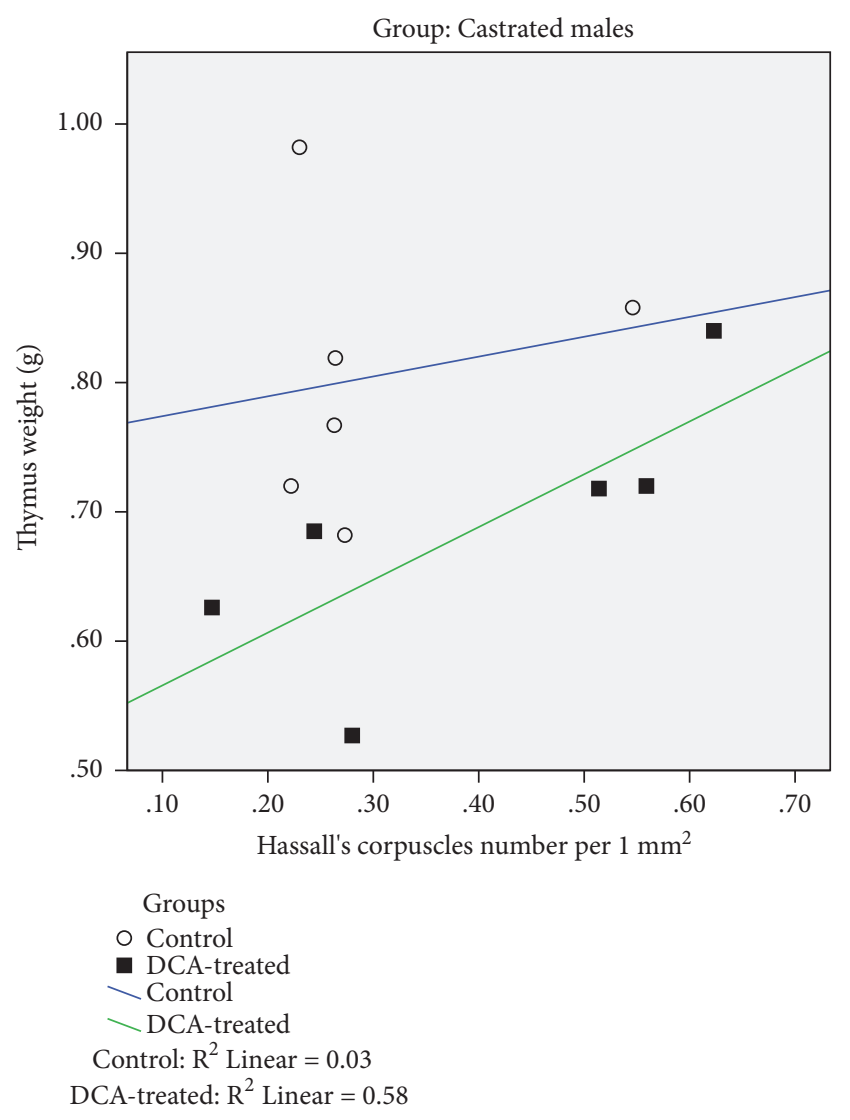

(b)

FIGURE 4: Correlation plots of the Hassall's corpuscles number per $1 \mathrm{~mm}^{2}$ in the thymus of gonad-intact (a) and castrated male (b) rat groups.

of action is to inhibit the PDHK, keeping the PDC in the unphosphorylated catalytically active form [5]. PDHK has been suggested as a specific target in proliferating cancer cells [13]. $\mathrm{PDH}$ is present in all tissues. Also, the DCA effect is related with a decrease of the blood lactate acid level [12]. Many aspects of the contribution of the DCA pharmacological mechanisms and their relationship with gender-related pathophysiological processes have not been investigated. PDH activity was higher in young female than in young male rats and decreased after ovariectomy but not 


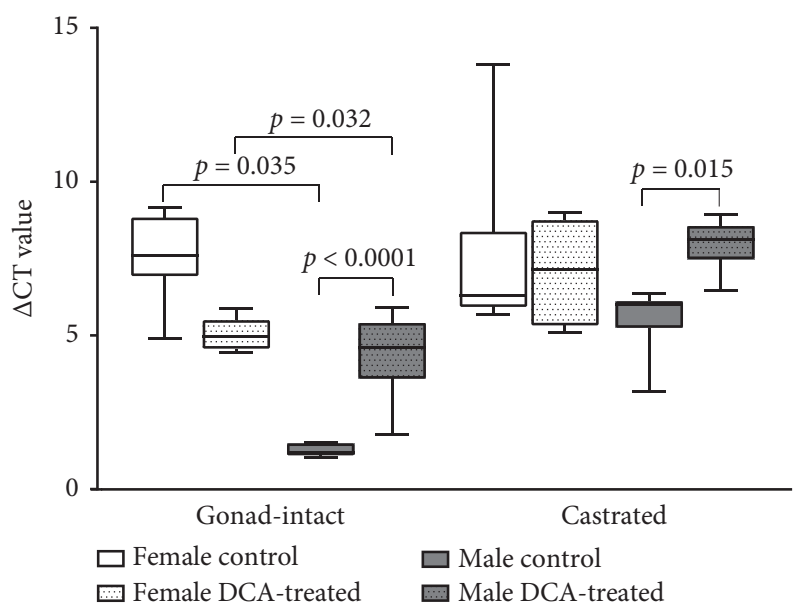

FIGURE 5: Slc12a2 RNA levels in the rats after normalization with Glpdh gene. Delta threshold cycle $(\Delta \mathrm{CT})$ method was used for this analysis; the lower the $\Delta \mathrm{CT}$, the higher the expression (the horizontal bars represent the average, the minimal, and maximal values are shown with short horizontal lines).

after orchidectomy [29]. Estradiol treatment increased the expression of several PDH subunits [30]. Eight out of 11 genes evaluated for the PDC had higher expression levels in adult male hearts compared to females [31].

The rat thymus could be a valuable model for investigating the impact of a medicinal product on thymocyte proliferation. The study tested the hypothesis that the influence of DCA on thymus weight might be gender-related. It was based on the recent published data in which DCA has been shown to decrease thymus weight in gonad-intact male rats [20]. To exclude the influence of gonadal hormones on thymus involution, castrated male and female rats were studied also. We expected that changes might occur in HCs because they represent the stage of thymic epithelial cell differentiation $[32,33]$ and participate in removing the matured or apoptotic thymocytes [34,35]. Both thymocytes and thymic epithelial cells possess androgen receptors [36].

A comparison of rat thymus weight of gonad-intact and castrated rats is related with a significant increase of thymus weight in castrated rats of both genders. Castration induces a thymus hyperplasia which is related with increased rat thymocyte proliferation [37]. Thymic involution is a complex process related with numerous molecular mechanisms, ageing, and gonad hormones included [38]. Androgens induce a decline of thymus weight in NZB mice, which results in the gender dimorphism of thymus weight between males and females [39]. In castrated female rats at the age of one month, the number of thymocytes and recent thymic emigrants in the peripheral blood was increased after a month as compared with the control animals [40]. The surgical and chemical castration of 12-month-old male rats caused regeneration of the atrophied thymus [41]. The Sprague-Dawley rat castration enhances thymic weight whilst gender hormones reduce the castration-induced thymus hypertrophy [42].

The study results show a decrease of thymus weight after four weeks of DCA treatment only in the gonad-intact males and females and no DCA treatment impact on thymus weight in the age-matched castrated DCA-treated male and female groups. These data indicate that the DCA acts on thymus weight synergistically with gonad hormones of both genders in gonad-intact males and females.

No relationship was determined between the thymus weight and the rat body weight in the tested DCA-treated groups of both genders despite the fact that castrated DCAtreated rat groups showed a significant body weight decrease; no rat body weight change was noted in the DCA-treated gonad-intact rat groups of both genders. A significant body weight decrease in DCA-treated castrated rats may indicate a change in the gonad-hormone-dependent DCA metabolism or a possible increased toxicity in the conditions of the reduced gonad hormone levels.

The Effect of Castration and DCA Treatment on the HCs in Rat Thymus. The study data indicate that the HCs appeared to be low in male and female thymus of gonad-intact control rat groups, and no gender-related difference was determined. These data confirm the literature data that HCs are poorly expressed in the thymus of rodents [43]. Tanaka et al. described HCs in spontaneous thymoma of 10-week-old Sprague-Dawley rats, and they were evaluated as medullar differentiation areas [44]. Rat castration is related with the increased HCs in female and male thymus [18].

The DCA treatment caused a significant increase of the HCs in the DCA-treated gonad-intact males as compared with their control, and no such increase in the DCA-treated gonad-intact females was found. There was gender-related difference in the HCs when comparing DCA-treated gonadintact males and females: males showed significantly higher $\mathrm{HCs}$, and no gender-related differences were found in the castrated DCA-treated groups when comparing the castrated control and castrated DCA-treated groups of both genders. The findings of DCA effect on thymus weight, on correlation between thymus weight and HCs may indicate that under the influence of DCA treatment the thymic epithelial cells undergo gender-related changes which could depend on the sex hormones.

In the thymus microenvironment, thymic epithelial cells are an important component supporting thymocyte development [45] which may be under the sex hormone control. When gonad-intact DCA-treated thymus diminishes in weight or increases in castrated animals, the increase in the HCs may have different pathophysiological mechanisms which can be related to the apoptotic thymocyte removal. Both thymic epithelial cells and thymocytes possess functional androgen receptors and can respond to testosterone [36]. The gonad-hormone-related mechanism of thymopoiesis is not clear; by using androgen-receptor knockout mice it was shown that thymic epithelial cells but not thymocytes or fibroblasts contribute to the determination of thymic cellularity [46]. The thymic epithelial cells in gonad-intact aged and in castrated male mice express similar sets of genes, and they are not altered after castration [47]. The mechanisms of the synergistic effect of DCA and testosterone on gonad-intact male thymus remain to be elucidated. 
The study indicates some thymic epithelial cells to transform into HCs after reduction of gonad hormones by castration of both gender rats. When castrated male and female animals were treated with DCA, we noticed the further tendency of increase in HCs in the thymus of both sexes, and it was more pronounced in males. This supports the findings of Gray et al. that the thymic stroma is a dynamic population of thymocytes, and it may play a more direct role in the selection of thymocytes [48]. The study results suggest that different mechanisms are responsible for changes in thymopoiesis and thymus epithelial cells transformation into HCs under the DCA influence in gonad-intact and castrated animals. The DCA influences the thymopoiesis suppressing thymocyte proliferation, and this effect was gender-related and more pronounced in gonad-intact male rats; in contrast, in castrated rats after DCA treatment such DCA effect was not expressed.

The DCA Effect on RNA Expression of NKCC1 in Thymus. The existence of NKCC1 in rat thymocytes was the background to check the influence of DCA on its activity. The NKCC1 functional activity in rat thymocytes was found to be related with the chloride anion influx sensitive to the NKCC inhibitor furosemide, indicating that part of the chloride influx is mediated by NKCC1 $[22,23,49]$.

The study shows that the DCA could target the NKCC1 protein where a gender-related difference of the DCA effect on the NKCC1 gene expression in rat thymus was determined. A significant difference was found between the $\Delta \mathrm{CT}$ values (expression difference in the Slc12a2 and Glpdh genes) in the DCA-treated gonad-intact and control males as well as in the castrated male groups. The Slc12a2 gene RNA expression level (the $2^{-\Delta \Delta C T}$ value) in the gonad-intact DCA-treated males was decreased by $90 \%$ under control conditions and significantly decreased (by 76\%) in the castrated males. No changes in the tested NKCC1 RNA gene expression level were determined in the studied gonad-intact and castrated female DCA-treated groups as compared with the control of both gonad-intact and castrated female rats.

There are two NKCC isoforms: NKCC1 and NKCC2; the $\mathrm{NKCC1}$ is distributed in various tissue types, among them in the thymus $[24,25]$ of different species [50]. NKCC1 mRNA levels were higher in males than in females on the day of birth, and the total NKCCl protein levels were higher in the embryonic male than in female hypothalamus [51].

The DCA increases the reactive oxygen species generation [52]. The DCA produces time- and concentrationdependent increase in the superoxide anion and nitric oxide production in zebrafish [53]. The DCA effect on NKCC1 might be related with the oxidative stress because the NKCC activity in different cell types is regulated by oxidation and nitration, and the NKCC activity may depend on the levels of free oxidative radicals or nitric oxide donors; free oxidative radicals and protein tyrosine nitration can affect the NKCC structure and its function; the NKCCl activity in endothelial cells was inhibited by the oxidant tertbutylhydroperoxide exposition $[54,55]$.

Young adult female mice have a lower oxidative stress and a higher pyruvate dehydrogenase complex activity as compared with young adult males, indicating that females may be better protected against the ROS damage. The depletion of steroids by ovariectomy potentially enhanced oxidative damage, whereas orchidectomy did not modify the oxidative stress parameters in mice [29]. The female rats showed a lower production of hydrogen peroxide in cardiac mitochondria as compared to males [56]. Increased formation of ROS inhibits the rat thymocyte proliferation [57].

The DCA treatment was reported to significantly reduce the thymus weight, and such changes are in concert with the DCA-induced increase of thymocyte percentage in the $G_{2}-M$ cycle phase and the reduced percentage of the $G_{0}-G_{1}$ phase [20]. The DCA-induced $\mathrm{G}_{2}-\mathrm{M}$ phase arrest in multiple myeloma cell lines induced by DCA was found also, where the described DCA effect supposed to be related with the oxidative stress caused by the DCA $[17,58]$. Additionally, the increased reactive oxygen species generation in relationship with DCA treatment appears with a concomitant cellular shift from glycolysis to oxidative metabolism, resulting in an increased apoptosis [59]. The DCA causes Treg induction and Th17 suppression in the T-cell differentiation process which is dependent on the reactive oxygen species [60].

The induction of NKCC1 RNA expression suppression indicates that DCA may be important in regulating the intracellular chloride thymocyte concentration. The impact on the intracellular chloride concentration would have the antiproliferative effect $[61,62]$. The NKCC1 plays an important role in cancer cell proliferation, apoptosis, invasion [6264], has a potential role in cancer progression of tumors with a high NKCC1 expression, and is recognized as a cancer therapeutic target [26].

DCA acts as inhibitor of glutathione S-transferase-zetal (GST $\zeta)$. Elimination of DCA including glutathione- (GSH-) dependent oxygenation to glyoxylic acid mainly depends on GST $\zeta$-catalyzed dechlorination by mitochondrial or cytosolic enzymes [65-67]. Regarding cytosolic GST $\zeta$, the ${ }^{\text {App }} K_{m}$ for GSH obtained in female rats is 2.5-3.2-fold higher than males; the higher ${ }^{\mathrm{App}} K_{\mathrm{m}}$ of GSH is associated with lower access or binding to GSH [67]. It has been reported that DCA metabolism could be gender- and sex hormone dependent in rats: activity of glycolate oxidase in gonad-intact females and gonadectomized male rats was significantly lower than in gonad-intact males ones (glycolate oxidase is involved in the conversion of DCA metabolite glycolic acid to oxalate in rat liver); testosterone increases and estrogens decrease activity of glycolate oxidase in male rats [68]. The preclinical studies of DCA metabolism were conducted only in male rats [69-74]. Data on DCA metabolism in males cannot be directly extrapolated to females. The scientific guidelines for the preclinical safety evaluation of pharmaceuticals require both genders to be used [75]; the principles of Good Clinical Practice require that the available nonclinical information on an investigational product should be adequate to support the proposed clinical research [76]; e.g., gender-related investigational medicines effects remain to be explored firstly by preclinical studies. 


\section{Conclusions}

(i) The DCA treatment decreases the thymus weight of gonad-intact rats of both genders, but such impact is absent in castrated rat groups, indicating the synergistic pharmacological mechanism of DCA and gonad hormones.

(ii) The different mechanisms are responsible for changes in thymus epithelial cells transformation into Hassall's corpuscles under the DCA effect in gonad-intact and castrated animals.

(iii) The DCA treatment decreases the NKCC1 gene RNA expression in the gonad-intact and castrated males, and no such effect was determined in females.

(iv) The investigation of the DCA treatment efficacy should be evaluated with regard to gender and the exposition of gonad hormones.

\section{Data Availability}

All data generated or analyzed during this study are included in this published article. The datasets used and/or analyzed during the current study are available from the corresponding author on reasonable request.

\section{Conflicts of Interest}

The authors declared no potential conflicts of interest with respect to the research, authorship, and/or publication of this article.

\section{Acknowledgments}

The present study was partially funded by research fund of the Lithuanian University of Health Sciences and by the Research Council of Lithuania.

\section{References}

[1] P. W. Stacpoole, "Therapeutic targeting of the pyruvate dehydrogenase complex/pyruvate dehydrogenase kinase (PDC/PDK) axis in cancer," Journal of the National Cancer Institute, vol. 109, no. 11, 2017.

[2] P. W. Stacpoole, G. N. Henderson, Z. Yan, R. Cornett, and M. O. James, "Pharmacokinetics, metabolism, and toxicology of dichloroacetate," Drug Metabolism Reviews, vol. 30, no. 3, pp. 499-539, 1998.

[3] E. Babu, S. Ramachandran, V. Coothankandaswamy et al., "Role of SLC5A8, a plasma membrane transporter and a tumor suppressor, in the antitumor activity of dichloroacetate HHS Public Access," Oncogene, vol. 22, no. 3038, pp. 4026-4037, 2011.

[4] A. L. Shroads, T. Langaee, B. S. Coats et al., "Human polymorphisms in the glutathione transferase zeta $1 /$ maleylacetoacetate isomerase gene influence the toxicokinetics of dichloroacetate," Clinical Pharmacology and Therapeutics, vol. 52, no. 6, pp. 837849, 2012.

[5] M. S. Patel and T. E. Roche, "Molecular biology and biochemistry of pyruvate dehydrogenase complexes," The FASEB Journal, vol. 4, no. 14, pp. 3224-3233, 1990.
[6] Z. H. Zhou, D. B. McCarthy, C. M. O’Connor, L. J. Reed, and J. K. Stoops, "The remarkable structural and functional organization of the eukaryotic pyruvate dehydrogenase complexes," Proceedings of the National Acadamy of Sciences of the United States of America, vol. 98, no. 26, pp. 14802-14807, 2001.

[7] H. H. Dahl, "Pyruvate dehydrogenase E1 alpha deficiency: males and females differ yet again," The American Journal of Human Genetics, vol. 56, no. 3, pp. 553-557, 1995.

[8] B. H. Robinson, K. Chun, N. Mackay, G. Otulakowski, R. Petrova-Benedict, and $\mathrm{H}$. Willard, "Isolated and combined deficiencies of the alpha-keto acid dehydrogenase complexes," Annals of the New York Academy of Sciences, vol. 573, pp. 337346, 1989.

[9] K. P. Patel, T. W. O’Brien, S. H. Subramony, J. Shuster, and P. W. Stacpoole, "The spectrum of pyruvate dehydrogenase complex deficiency: clinical, biochemical and genetic features in 371 patients," Molecular Genetics and Metabolism, vol. 105, no. 1, pp. 34-43, 2012.

[10] T. Hitosugi, J. Fan, T.-W. Chung et al., "Tyrosine phosphorylation of mitochondrial pyruvate dehydrogenase kinase 1 is important for cancer metabolism," Molecular Cell, vol. 44, no. 6, pp. 864-877, 2011.

[11] G. Sutendra, P. Dromparis, A. Kinnaird et al., "Mitochondrial activation by inhibition of PDKII suppresses HIFla signaling and angiogenesis in cancer," Oncogene, vol. 32, no. 13, pp. 1638$1650,2013$.

[12] P. W. Stacpoole, L. R. Gilbert, R. E. Neiberger et al., "Evaluation of long-term treatment of children with congenital lactic acidosis with dichloroacetate," Pediatrics, vol. 121, no. 5, pp. el223e1228, 2008.

[13] S.-L. Zhang, X. Hu, W. Zhang, and K. Y. Tam, "Unexpected discovery of dichloroacetate derived adenosine triphosphate competitors targeting pyruvate dehydrogenase kinase to inhibit cancer proliferation," Journal of Medicinal Chemistry, vol. 59, no. 7, pp. 3562-3568, 2016.

[14] S. L. Archer, M. Gomberg-Maitland, M. L. Maitland, S. Rich, J. G. N. Garcia, and E. K. Weir, "Mitochondrial metabolism, redox signaling, and fusion: a mitochondria-ROS-HIF- $1 \alpha-$ Kv1.5 O 2 -sensing pathway at the intersection of pulmonary hypertension and cancer," American Journal of Physiology-Heart and Circulatory Physiology, vol. 294, no. 2, pp. H570-H578, 2008.

[15] E. D. Michelakis, L. Webster, and J. R. Mackey, "Dichloroacetate (DCA) as a potential metabolic-targeting therapy for cancer," British Journal of Cancer, vol. 99, no. 7, pp. 989-994, 2008.

[16] C. Abildgaard, C. Dahl, A. L. Basse, T. Ma, and P. Guldberg, "Bioenergetic modulation with dichloroacetate reduces the growth of melanoma cells and potentiates their response to BRAFV600E inhibition," Journal of Translational Medicine, vol. 12, article 247, 2014.

[17] S. Bonnet, S. L. Archer, J. Allalunis-Turner et al., "A mitochondria- $\mathrm{K}+$ channel axis is suppressed in cancer and its normalization promotes apoptosis and inhibits cancer growth," Cancer Cell, vol. 11, no. 1, pp. 37-51, 2007.

[18] A. Valančiūtè, R. Mozuraite, I. Balnyte, J. Didžiapetrienè, P. Matusevičius, and D. Stakišaitis, "Sodium valproate effect on the structure of rat glandule thymus: gender-related differences," Experimental and Toxicologic Pathology, vol. 67, no. 7-8, pp. 399406, 2015.

[19] N. Watanabe, Y. H. Wang, H. K. Lee, T. Ito, W. Cao, and Y. Liu, "Hassall's corpuscles instruct dendritic cells to induce 
CD4+CD25+ regulatory T cells in human thymus," Nature, vol. 436, no. 7054, pp. 1181-1185, 2005.

[20] J. Stanevičiūtè, D. Urbonienè, A. Valančiūtè et al., "The effect of dichloroacetate on male rat thymus and on thymocyte cell cycle," International Journal of Immunopathology and Pharmacology, vol. 29, no. 4, pp. 818-822, 2016.

[21] J. Stanevičiūtè, M. Juknevičienè, J. Palubinskienè et al., "Sodium dichloroacetate pharmacological effect as related to $\mathrm{Na}-\mathrm{K}-2 \mathrm{Cl}$ cotransporter inhibition in rats," Dose-Response, vol. 16, no. 4, Article ID 155932581881152, 2018.

[22] A. Juška and D. Stakišaitis, "Chloride/bicarbonate exchanger in rat thymic lymphocytes: Experimental investigation and mathematical modeling," Trace elements and Electrolytes, vol. 30, no. 4, pp. 167-172, 2013.

[23] D. Stakisaitis, M. S. Lapointe, and D. Batlle, "Mechanisms of chloride transport in thymic lymphocytes," American Journal of Physiology-Renal Physiology, vol. 280, no. 2, pp. F314-F324, 2001.

[24] R. Jalali, J. C. Lodder, B. Zandieh-Doulabi et al., "The role of $\mathrm{Na}: \mathrm{K}: 2 \mathrm{Cl}$ cotransporter 1 (NKCC1/SLC12A2) in dental epithelium during enamel formation in mice," Frontiers in Physiology, vol. 8, no. 924, 2017.

[25] National Center for Biotechnology Information Support Center, "Slc12a2 solute carrier family 12 member 2 [Rattus norvegicus4 (Norway rat)]," 2019, https://www.ncbi.nlm.nih .gov/gene/83629.

[26] D. Cong, W. Zhu, J. S. Kuo, S. Hu, and D. Sun, "Ion transporters in brain tumors," Current Medicinal Chemistry, vol. 22, no. 10, pp. 1171-1181, 2015.

[27] J. A. Clayton and F. S. Collins, "Policy: NIH to balance sex in cell and animal studies," Nature, vol. 509, no. 7500, pp. 282-283, 2014.

[28] R. Mikušová, V. Mešt’anová, Š. Polák, and I. Varga, "What do we know about the structure of human thymic Hassall's corpuscles? A histochemical, immunohistochemical, and electron microscopic study," Annals of Anatomy, vol. 211, pp. 140-148, 2017.

[29] P. Gaignard, S. Savouroux, P. Liere et al., "Effect of sex differences on brain mitochondrial function and its suppression by ovariectomy and in aged mice," Endocrinology, vol. 156, no. 8, pp. 2893-2904, 2015.

[30] J. Nilsen, R. W. Irwin, T. K. Gallaher, and R. D. Brinton, "Estradiol in vivo regulation of brain mitochondrial proteome," The Journal of Neuroscience, vol. 27, no. 51, pp. 14069-14077, 2007.

[31] M. T. Andrews, "Genes controlling the metabolic switch in hibernating mammals," Biochemical Society Transactions, vol. 32, no. 6, pp. 1021-1024, 2004.

[32] A. J. White, K. Nakamura, W. E. Jenkinson et al., "Lymphotoxin signals from positively selected thymocytes regulate the terminal differentiation of medullary thymic epithelial cells," The Journal of Immunology, vol. 185, no. 8, pp. 4769-4776, 2010.

[33] M. Yano, N. Kuroda, H. Han et al., "Aire controls the differentiation program of thymic epithelial cells in the medulla for the establishment of self-tolerance," The Journal of Experimental Medicine, vol. 205, no. 12, pp. 2827-2838, 2008.

[34] J. N. Blau and N. Veall, "The uptake and localization of proteins, evans blue and carbon black in the normal and pathological thymus of the guinea-pig," The Journal of Immunology, vol. 12, no. 4, pp. 363-372, 1967.

[35] R. Senelar, M. J. Escola, R. Escola, B. Serrou, and A. Serre, "Relationship between Hassall's corpuscles and thymocytes fate in guinea-pig foetus," Biomedicine, vol. 24, no. 2, pp. 112-122, 1976.

[36] N. J. Olsen, G. Olson, S. M. Viselli, X. Gu, and W. J. Kovacs, "Androgen receptors in thymic epithelium modulate thymus size and thymocyte development 1," Endocrinology, vol. 142, no. 3, pp. 1278-1283, 2001.

[37] T. Schneider, A. Roman, A. Basta-Kaim et al., "Gender-specific behavioral and immunological alterations in an animal model of autism induced by prenatal exposure to valproic acid," Psychoneuroendocrinology, vol. 33, no. 6, pp. 728-740, 2008.

[38] G. Leposavić and M. Perišić, "Age-associated remodeling of thymopoiesis: role for gonadal hormones and catecholamines," Neuroimmunomodulation, vol. 15, no. 4-6, pp. 290-322, 2008.

[39] L. O. Simpson, "Studies on the NZB mouse thymus. I. Thymus weight relationships to age and body weight from birth to old age," American Journal of Anatomy, vol. 141, no. 1, pp. 127-132, 1974.

[40] M. Perišić, Z. Stojić-Vukanić, I. Pilipović et al., "Role of ovarian hormones in T-cell homeostasis: from the thymus to the periphery," Immunobiology, vol. 218, no. 3, pp. 353-367, 2013.

[41] F. Dorko, D. Kluchová, A. Boleková, T. Špakovská, T. Borošová, and K. Lovasová, "Influence of surgical and chemical orchidectomy on weight and distribution of AChE-nerve fibres in thymuses of adult rats," European Journal of Histochemistry, vol. 55 , no. 3, p. 22, 2011.

[42] K. F. Windmill and V. W. K. Lee, "Influences of surgical castration on the thymus of male rats," Journal of Reproductive Immunology, vol. 44, no. 1-2, pp. 29-39, 1999.

[43] A. G. Farr, J. L. Dooley, and M. Erickson, "Organization of thymic medullary epithelial heterogeneity: Implications for mechanisms of epithelial differentiation," Immunological Reviews, vol. 189, pp. 20-27, 2002.

[44] H. Tanaka, S. Suzuki, F. Ninomiya, K. Matsubara, and K. Hakoi, "Spontaneous thymoma in a 10-week-old sprague-dawley rat," Journal of Toxicologic Pathology, vol. 25, no. 1, pp. 37-40, 2012.

[45] L. Sun, H. Li, H. Luo, and Y. Zhao, "Thymic epithelial cell development and its dysfunction in human diseases," BioMed Research International, vol. 2014, Article ID 206929, 14 pages, 2014.

[46] K.-P. Lai, J.-J. Lai, P. Chang et al., "Targeting thymic epithelia AR enhances T-cell reconstitution and bone marrow transplant grafting efficacy," Molecular Endocrinology, vol. 27, no. 1, pp. 2537, 2013.

[47] A. V. Griffith, M. Fallahi, T. Venables, and H. T. Petrie, "Persistent degenerative changes in thymic organ function revealed by an inducible model of organ regrowth," Aging Cell, vol. 11, no. 1, pp. 169-177, 2012.

[48] D. H. D. Gray, N. Seach, T. Ueno et al., "Developmental kinetics, turnover, and stimulatory capacity of thymic epithelial cells," Blood, vol. 108, no. 12, pp. 3777-3785, 2006.

[49] P. Hannaert, M. Alvarez-Guerra, D. Pirot, C. Nazaret, and R. Garay, "Rat NKCC2/NKCC1 cotransporter selectivity for loop diuretic drugs," Naunyn-Schmiedeberg's Archives of Pharmacology, vol. 365, no. 3, pp. 193-199, 2002.

[50] J.-C. Xu, C. Lytle, T. T. Zhu, J. A. Payne, E. Benz Jr., and B. Forbush III, "Molecular cloning and functional expression of the bumetanide-sensitive Na-K-Cl cotransporter," Proceedings of the National Acadamy of Sciences of the United States of America, vol. 91, no. 6, pp. 2201-2205, 1994.

[51] T. S. Perrot-Sinal, C. J. Sinal, J. C. Reader, D. B. Speert, and M. M. Mccarthy, "Sex differences in the chloride cotransporters, 
$\mathrm{NKCC1}$ and KCC2, in the developing hypothalamus," Journal of Neuroendocrinology, vol. 19, no. 4, pp. 302-308, 2007.

[52] V. N. Jackson and A. P. Halestrap, "The kinetics, substrate, and inhibitor specificity of the monocarboxylate (lactate) transporter of rat liver cells determined using the fluorescent intracellular $\mathrm{pH}$ indicator, $2^{\prime}, 7^{\prime}$-bis(carboxyethyl)-5(6)carboxyfluorescein," The Journal of Biological Chemistry, vol. 271, no. 2, pp. 861-868, 1996.

[53] E. Hassoun, C. Kariya, and F. E. Williams, "Dichloroacetateinduced developmental toxicity and production of reactive oxygen species in zebrafish embryos," Journal of Biochemical and Molecular Toxicology, vol. 19, no. 1, pp. 52-58, 2005.

[54] A. R. Jayakumar, M. Liu, M. Moriyama et al., "Na-K-Cl cotransporter-1 in the mechanism of ammonia-induced astrocyte swelling," The Journal of Biological Chemistry, vol. 283, no. 49, pp. 33874-33882, 2008.

[55] S. J. Elliott and W. P. Schilling, "Oxidant stress alters $\mathrm{Na}+$ pump and $\mathrm{Na}(+)-\mathrm{K}(+)-\mathrm{Cl}$ - cotransporter activities in vascular endothelial cells," American Journal of Physiology-Heart and Circulatory Physiology, vol. 263, no. 1, pp. H96-H102, 1992.

[56] V. Vijay, T. Han, C. L. Moland, J. C. Kwekel, J. C. Fuscoe, and V. G. Desai, "Sexual dimorphism in the expression of mitochondria-related genes in rat heart at different ages," PLoS ONE, vol. 10, no. 1, Article ID e0117047, 2015.

[57] U. R. Aulwurm and K. A. Brand, "Increased formation of reactive oxygen species due to glucose depletion in primary cultures of rat thymocytes inhibits proliferation," European Journal of Biochemistry, vol. 267, no. 18, pp. 5693-5698, 2000.

[58] W. Y. Sanchez, S. L. McGee, T. Connor et al., "Dichloroacetate inhibits aerobic glycolysis in multiple myeloma cells and increases sensitivity to bortezomib," British Journal of Cancer, vol. 108, no. 8, pp. 1624-1633, 2013.

[59] X. X. Stander, B. A. Stander, and A. M. Joubert, "Synergistic anticancer potential of dichloroacetate and estradiol analogue exerting their effect via ROS-JNK-Bcl-2-mediated signalling pathways," Cellular Physiology and Biochemistry, vol. 35, no. 4, pp. 1499-1526, 2015.

[60] N. Makita, J. Ishiguro, K. Suzuki, and F. Nara, "Dichloroacetate induces regulatory T-cell differentiation and suppresses Th17-cell differentiation by pyruvate dehydrogenase kinaseindependent mechanism," Journal of Pharmacy and Pharmacology, vol. 69, no. 1, pp. 43-51, 2017.

[61] S. Tanaka, H. Miyazaki, A. Shiozaki, D. Ichikawa, E. Otsuji, and Y. Marunaka, "Cytosolic Cl- affects the anticancer activity of paclitaxel in the gastric cancer cell line, MKN28 cell," Cellular Physiology and Biochemistry, vol. 42, no. 1, pp. 68-80, 2017.

[62] K. Hiraoka, H. Miyazaki, N. Niisato et al., "Chloride ion modulates cell proliferation of human androgen-independent prostatic cancer cell," Cellular Physiology and Biochemistry, vol. 25, no. 4-5, pp. 379-388, 2010.

[63] J. M. Russell, "Sodium-potassium-chloride cotransport," Physiological Reviews, vol. 80, no. 1, pp. 211-276, 2000.

[64] E. Maeno, N. Takahashi, and Y. Okada, "Dysfunction of regulatory volume increase is a key component of apoptosis," FEBS Letters, vol. 580, no. 27, pp. 6513-6517, 2006.

[65] R. Cornett, M. O. James, G. N. Henderson, J. Cheung, A. L. Shroads, and P. W. Stacpoole, "Inhibition of glutathione Stransferase zeta and tyrosine metabolism by dichloroacetate: a potential unifying mechanism for its altered biotransformation and toxicity," Biochemical and Biophysical Research Communications, vol. 262, no. 3, pp. 752-756, 1999.
[66] Z. Tong, P. G. Board, and M. W. Anders, "Glutathione transferase Zeta catalyses the oxygenation of the carcinogen dichloroacetic acid to glyoxylic acid," Biochemical Journal, vol. 331, no. 2, pp. 371-374, 1998.

[67] W. Li, M. O. James, S. C. McKenzie, N. A. Calcutt, C. Liu, and P. W. Stacpoole, "Mitochondrion as a novel site of dichloroacetate biotransformation by glutathione transferase 1," The Journal of Pharmacology and Experimental Therapeutics, vol. 336, no. 1, pp. 87-94, 2011.

[68] H. Yoshihara, S. Yamaguchi, and S. Yachiku, "Effect of sex hormones on oxalate-synthesizing enzymes in male and female rat livers," The Journal of Urology, vol. 161, no. 2, pp. 668-673, 1999.

[69] G. Lukas, K. H. Vyas, S. D. Brindle, A. R. Le Sher, and W. E. Wagner, "Biological disposition of sodium dichloroacetate in animals and humans after intravenous administration," Journal of Pharmaceutical Sciences, vol. 69, no. 4, pp. 419-421, 1980.

[70] J. L. Larson and R. J. Bull, "Metabolism and lipoperoxidative activity of trichloroacetate and dichloroacetate in rats and mice," Toxicology and Applied Pharmacology, vol. 115, no. 2, pp. 268-277, 1992.

[71] A. Gonzalez-Leon, I. R. Schultz, G. Xu, and R. J. Bull, "Pharmacokinetics and metabolism of dichloroacetate in the F344 rat after prior administration in drinking water," Toxicology and Applied Pharmacology, vol. 146, no. 2, pp. 189-195, 1997.

[72] M. O. James, Z. Yan, R. Cornett et al., "Pharmacokinetics and metabolism of dichloroacetate in male sprague-dawley rats: identification of glycine conjugates, including hippurate, as urinary metabolites of dichloroacetate," Drug Metabolism and Disposition, vol. 26, no. 11, pp. 1134-1143, 1998.

[73] S. A. Saghir and I. R. Schultz, "Low-dose pharmacokinetics and oral bioavailability of dichloroacetate in naive and GST-zetadepleted rats," Environmental Health Perspectives, vol. 110, no. 8, pp. 757-763, 2002.

[74] A. L. Shroads, X. Guo, V. Dixit, H. Liu, M. O. James, and P. W. Stacpoole, "Age-dependent kinetics and metabolism of dichloroacetate: possible relevance to toxicity," Journal of Pharmacology and Experimental Therapeutics, vol. 324, no. 3, pp. 1163-1171, 2009.

[75] "ICH guideline S6 (R1) - preclinical safety evaluation of biotechnology-derived pharmaceuticals Part I (Parent guideline) Preclinical safety evaluation of biotechnologyderived pharmaceuticals," http://www.ema.europa.eu/docs/en_GB/ document_library/Scientific_guideline/2009/09/WC500002828 .pdf.

[76] "Guideline for good clinical practice E6(R2)," http://www.ema .europa.eu/docs/en_GB/document_library/Scientific_guideline/ 2009/09/WC500002874.pdf. 


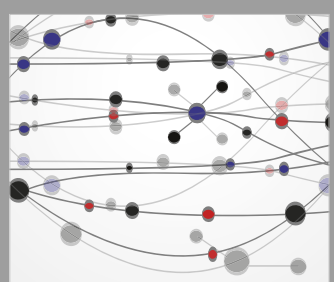

The Scientific World Journal
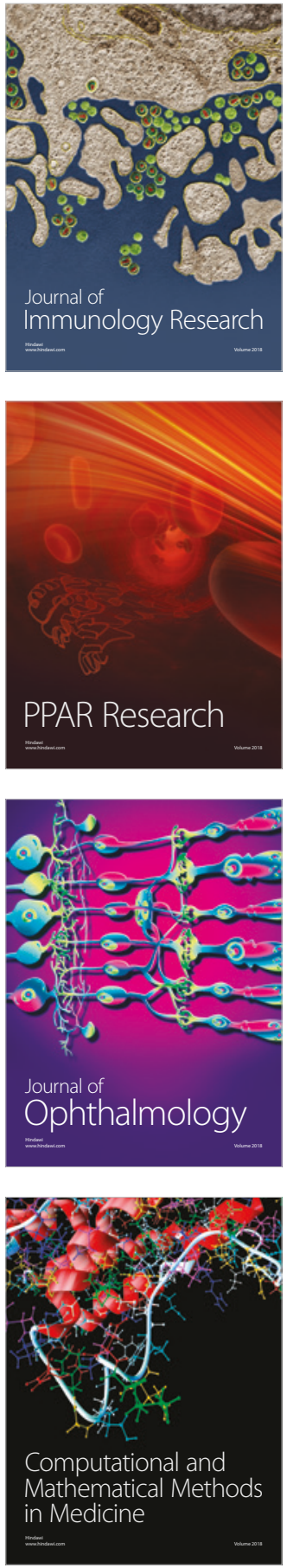

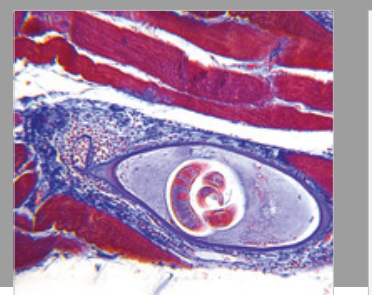

Gastroenterology Research and Practice

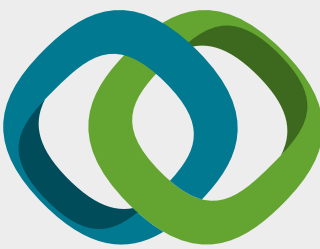

\section{Hindawi}

Submit your manuscripts at

www.hindawi.com
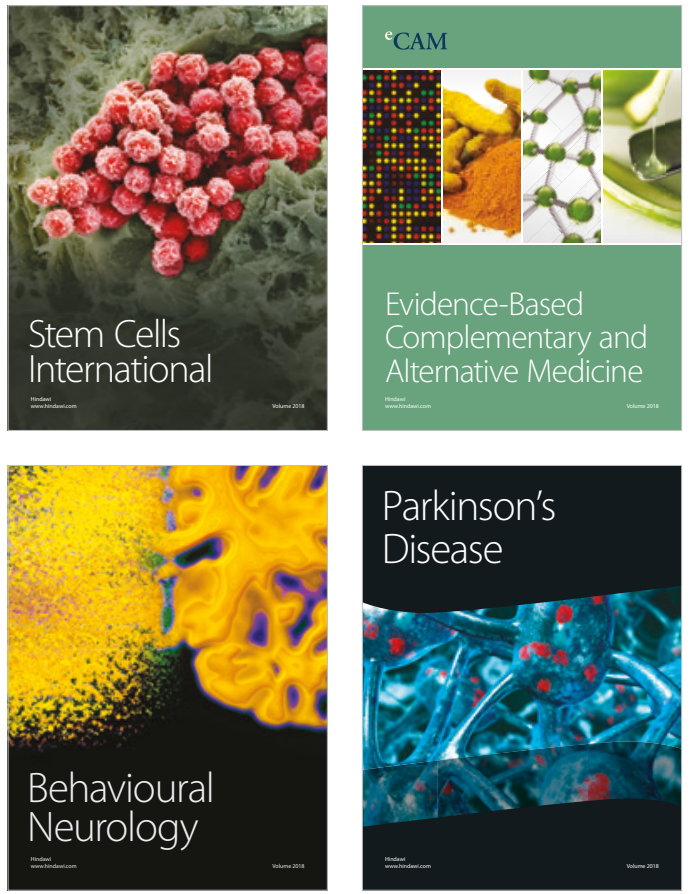

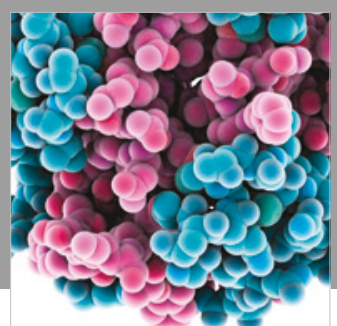

ournal of

Diabetes Research

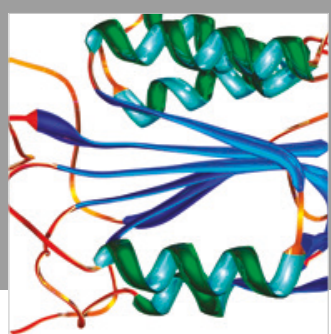

Disease Markers
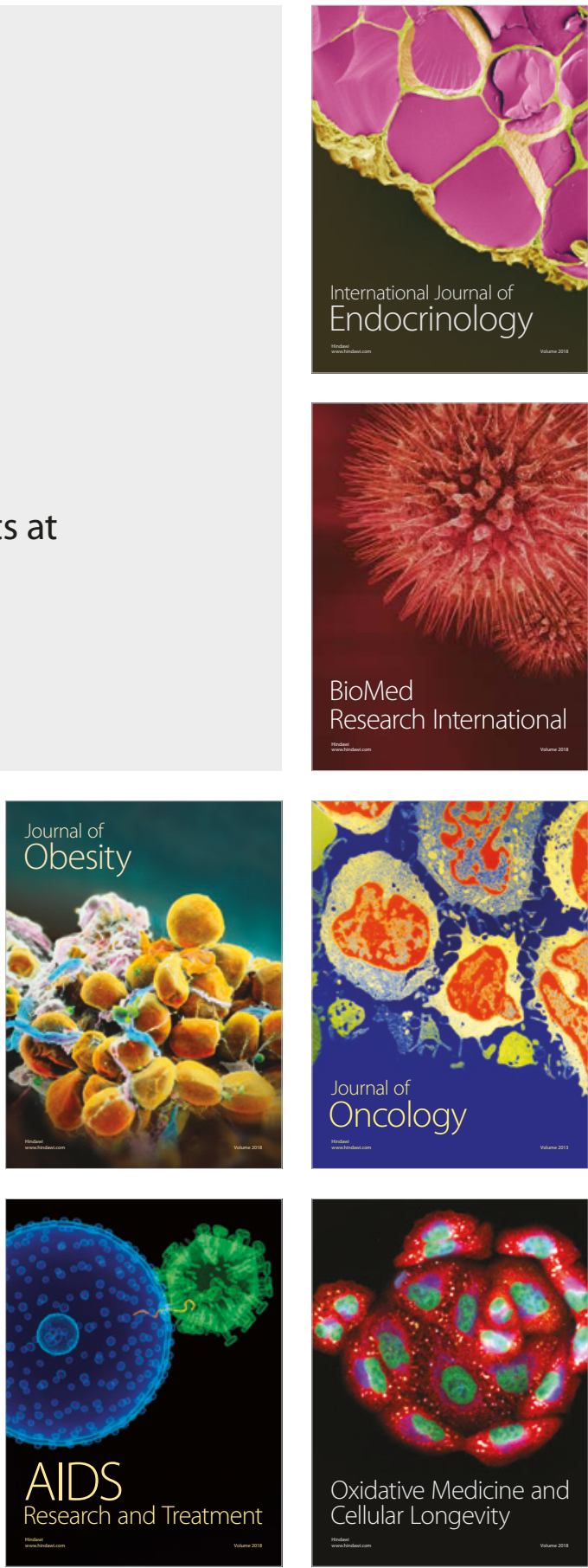